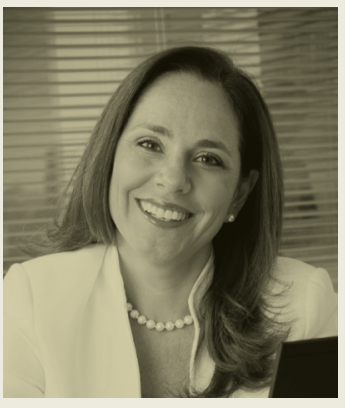

\title{
PREPARE-SE PARA 0 FUTURO DO TRABALHO
}

Mudanças nos padrões sociais, econômicos, tecnológicos e culturais estão alterando rapidamente a natureza e os tipos de trabalho em diversas áreas. No entanto, o Brasil não está conseguindo dar conta do desafio. Enquanto a tecnologia cresce exponencialmente, a produtividade evolui linearmente. Questões como desigualdade de renda, cenário político instável e, principalmente, desigualdade educacional são alguns fatores que contribuem para esse descompasso.

Por mais que o número de instituições de ensino superior tenha crescido, estudos comprovam que mesmo os alunos com acesso às melhores universidades do país têm perdido competitividade nos processos seletivos, por não demonstrarem as novas competências que os mercados atual e futuro exigem. Isso significa que ainda temos caminhos importantes a percorrer, no sentido de suprir deficits existentes.

Se o futuro do trabalho mostra que trabalharemos por mais tempo e que nossos conhecimentos e habilidades já estarão obsoletos em cerca de cinco anos, como vamos nos preparar para atuar nesse novo cenário? Grande parte do nosso modelo educacional ainda se apoia em um percurso formativo distante da nova realidade que se apresenta. Falta prática.

Como podemos transformar a carreira para que ela se adapte ao que está por vir? Essa reflexão nos motivou a realizar um estudo global, entre 2016 e 2017, lançado recentemente pelo Grupo Cia de Talentos, no qual elencamos seis tendências para o futuro da educação:

1) Indivíduo $S / A$ : o profissional que você quer ser é o que determinará o caminho a ser percorrido. Não será mais o diploma ou o certificado da pós-graduação que definirá a nova geração de profissionais; é você quem buscará formas inovadoras de aprendizagem para construir seu próprio conhecimento;

2) "Futurabilidades": as habilidades que nos trouxeram até aqui não serão suficientes para nos levar até onde queremos chegar. Seremos desafiados constantemente a descobrir respostas que ainda não estão disponíveis em nenhum lugar;

3) Aprendizagem nonstop: é o momento de admitir que pouco sabemos, que aprender será o único caminho para os novos tempos, que algo novo - e incrível - está acontecendo em algum lugar e que sempre é tempo de sermos aprendizes;

4) Fim das fronteiras: a educação está mais distribuída, colaborativa e compartilhada. Chegou o tempo de romper as fronteiras das salas de aula. É preciso ocupar novos espaços para impactar mais pessoas. Tenha o mundo, as cidades e os outros como plataforma de educação;

5) Saber coletivo: todo mundo tem algo para ensinar e para aprender. Os talentos estão dispersos em cada um de nós. Em rede, conseguimos unir diversas inteligências para resolver os mais complexos problemas;

6) Alquimistas da aprendizagem: o que não falta é conteúdo e acesso facilitado a ele, porém o complicador é determinar o que de fato importa saber. Tudo está à nossa disposição, mas é cada vez mais difícil escolher. $\mathrm{O}$ futuro da educação passa pela curadoria, ou seja, personalização e facilitação do conteúdo que importa de verdade.

A boa notícia fica por conta do crescente número de iniciativas de educação informal, além de escolas e universidades com propostas alternativas de ensino, que buscam quebrar paradigmas. É preciso repensar o papel do professor e as formas de aprendizagem. A evolução da educação também passa pela valorização do desenvolvimento de competências comportamentais e socioemocionais, que são de extrema relevância para as pessoas na construção de suas jornadas como cidadãos, profissionais e agentes das mudanças que queremos ver e fazer no mundo. 